\title{
The identification of plant reliefs in the Lalitavistara story of Borobudur temple, Central Java, Indonesia
}

\author{
DESTARIO METUSALA ${ }^{1, \vartheta}$, FAUZIAH $^{1, \bullet \vartheta}$, DEWI AYU LESTARI ${ }^{1, \vee v », ~ J A N I S ~ D A M A I Y A N I ~}{ }^{1,}$ \\ SHOFIYATUL MAS'UDAH ${ }^{1}$, HARI SETYAWAN ${ }^{2}$ \\ ${ }^{1}$ Purwodadi Botanic Gardens, Research Center for Plant Conservation and Botanic Gardens, Indonesian Institute of Sciences. Jl. Surabaya-Malang Km. \\ 65, Purwodadi, Pasuruan 67163, East Java, Indonesia. Tel./fax.: +62-341-426046, `email: metusala.destario@gmail.com, ” fauziahkrp@ gmail.com, \\ vwchunyang_dee@yahoo.co.id \\ ${ }^{2}$ Borobudur Conservation Office. J1. Badrawati, Borobudur, Magelang 56553, Central Java, Indonesia
}

Manuscript received: 26 February 2020. Revision accepted: 25 April 2020.

\begin{abstract}
Metusala D, Fauziah, Lestari DA, Damaiyani J, Mas'udah S, Setyawan H. 2020. The identification of plant reliefs in the Lalitavistara story of Borobudur temple, Central Java, Indonesia. Biodiversitas 21: 2206-2215. The Lalitavistara sutra is one of the central texts in the Mahayana tradition and it describes the life of the Buddha. This sutra has been carved in a good detail into 120 relief panels. These reliefs showed many plant figures that have often been carved in proper shape, so that made it possible for identification. The identification results showed that there were at least 63 species of plants in the Lalitavistara relief at Borobudur and these more various than species mentioned in the Lalitavistara sutra. Some species even only be found on reliefs but not in the text. These findings have indicated several important points; (i). the ancient Javanese community at that time already had a high awareness of the plant diversity, (ii). the plant figures as component in building atmosphere/background have been used by the carver as an opportunity for improvisation, (iii). the plant reliefs in Borobudur can be seen to reflect the surrounding plant diversity at the time, and (iv). the identification of plant reliefs in Borobudur can be used as an approach to understand the perspective of an ancient Javanese community on the importance of plant diversity.
\end{abstract}

Keywords: Borobudur, Lalitavistara, plant diversity, relief

\section{INTRODUCTION}

The Borobudur Temple is the largest Buddhist temple in the world and one of the important cultural achievements in ancient Javanese period. The stone wall reliefs of this temple illustrate some of the most important stories in the Buddhist tradition that cannot be found anywhere else except in Borobudur (Anandadjoti 2017).

The monument was built by the Syailendra Dynasty between 778 to $824 \mathrm{AD}$, located in Magelang, in the southern part of Central Java-Indonesia (Gunarto 2011). Borobudur was put on the UNESCO World Heritage list in 1991 with serial number 592 (Susilo and Suroso 2014). The Borobudur temple is used as the main source of history and culture in Indonesia and is valued as an extraordinary cultural heritage nowadays (Miksic and Tranchini 1990; Hermawan et al. 2016). The decoration of Borobudur temple has 2,672 relief panels consisting of decorative and narrative relief which narrate the story of the Buddha. In addition, also there are 504 Buddha statues and various stupas. The Borobudur temple was built consisting of five square terraces on a pyramidal base, three circular platforms in the middle part, and on the top with a dome as the highest point (Setyawan 2017).

Relief of Borobudur is rich in human anatomical forms, plant and animal figures, also form of environmental components such as water, cloud, and stones (Hidayanto 2014; Anandadjoti 2017). The tree or plant figures in relief have been carved specifically because they may be related to human life (Rohyani 2004; Istari 2015). Plant diversity usually provides benefits as cultural and important values to people's communities (Helida et al. 2015). The other studies showed that the relief of the Borobudur temple depicts the daily activities of the ancient Javanese community (Kempers et al. 1974; Setyawan and Kasatriyanto 2019). Therefore, identifying and analyzing the plant figures that appeared in relief could provide important information about the relationship between plants and local community at that time.

There are several previous studies that have observed the plant and animal figures appeared in Borobudur reliefs (Cammerloher 1931; Brink 1931; Steinman 1934; Sunaryo 2010; Setyawan and Kasatriyanto 2019). However, most of those previous studies are only pick some of relief figures as few purposive samples and without comparison analysis to the religious text as the source of inspiration. Perhaps, there is still no comprehensive identification study covering all plant figures appeared in every relief story in Borobudur. A total of 1460 story relief panels of Borobudur temple range from Kamadhatu to Rupadhatu (from the foot of the temple until the body of the temple). These 1460 relief panels are divided into five, based on the texts that are their source, namely Karmawibhangga, Lalitavistara, Jataka, Avadana, and Gandavyuha. Among these five stories in Borobudur, Lalitavistara is containing the fewest number of reliefs (120 panels). Lalitavistara reliefs depict the life of the Buddha, from his life in Tusita heaven up to his awakening and first teachings (Gunarto 
2011; Leouw 2012; Anandadjoti 2017). Therefore, Lalitavistara can be an ideal preliminary model in studying plant relief in Borobudur. Therefore, the aim of this study was to identify the diversity of plant figures carved on all 120 panels of Lalitavistara reliefs.

\section{MATERIALS AND METHODS}

\section{Study area}

This research is a part of National Priority Program in the International Biodiversity, Strategic and Action Plan (IBSAP) for biodiversity utilization component. This research was conducted in Borobudur temple area, Magelang, Central Java, Indonesia (Figure 1) on June 23-30, 2019.

\section{Procedures}

Inventory and documentation of plant figures in Lalitavistara relief, Borobudur temple

The inventory of plant figures in Lalitavistara relief, Borobudur temple used direct observation of the reliefs to document the details of flora species encountered (Figure 2.A). The data documentation technique was carried out by direct photography of the Lalitavistara relief panel (Figure 2.B). The Lalitavistara relief consists of 120 panels carved starting from the east side around the temple and can be read by circling the gallery in a clockwise direction or pradaksina (Soekmono 1973), beginning from the main wall, hallway I, top row (Figure 2.C).

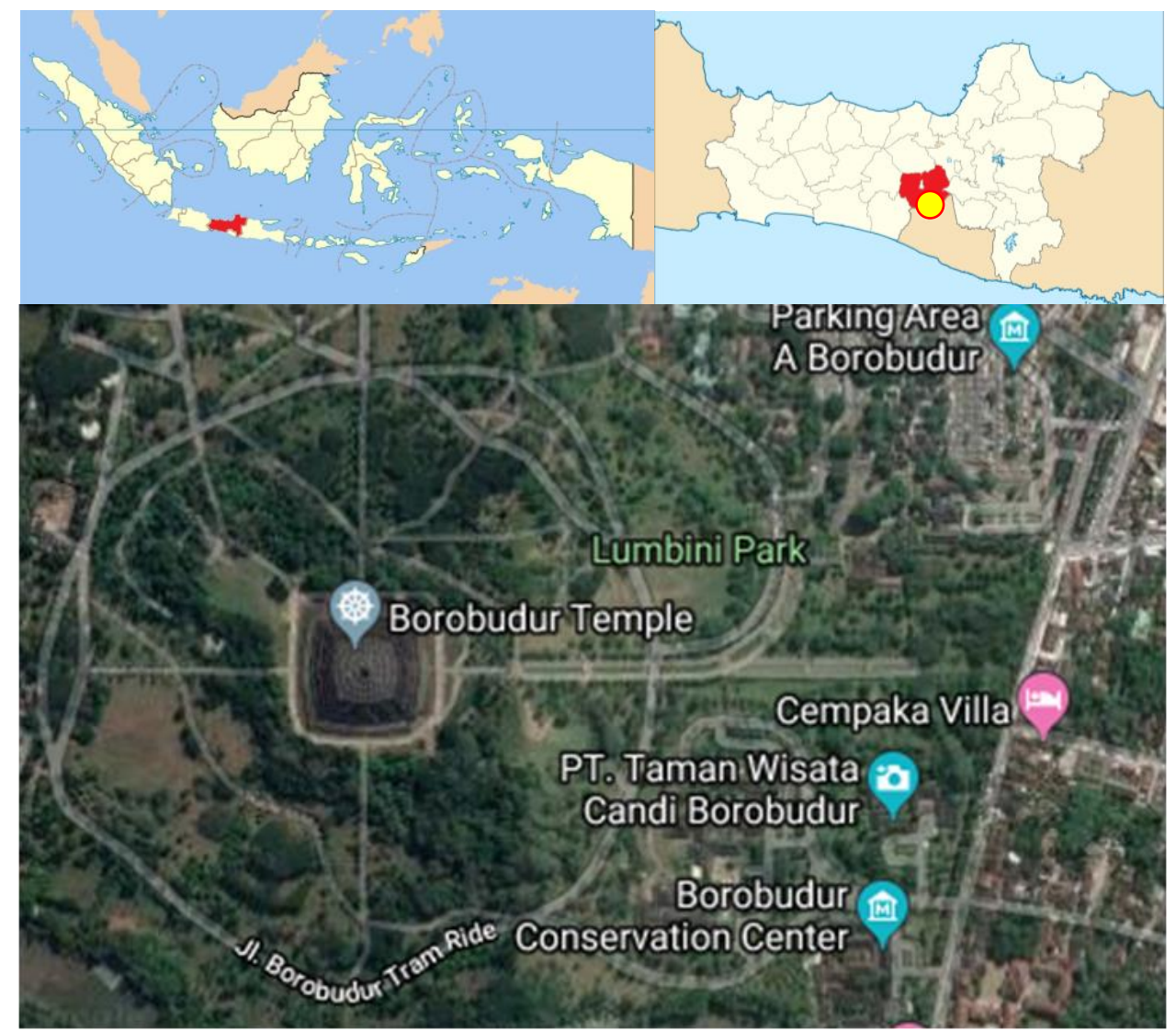

Figure 1. Location of Borobudur temple, Magelang, Central Java, Indonesia
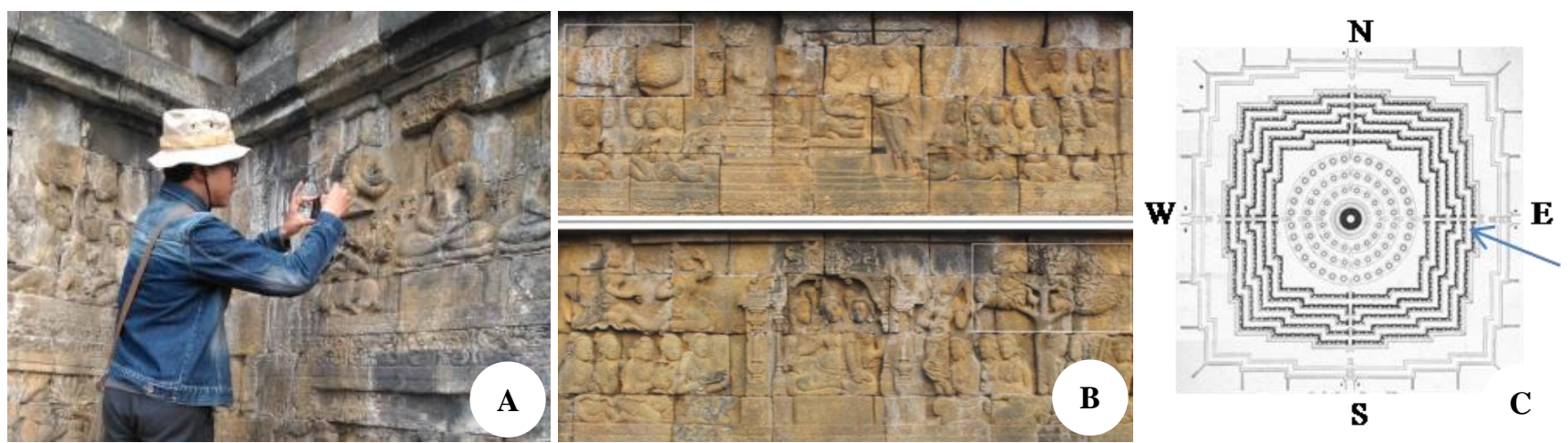

Figure 2. Documentation of plant figures in Lalitavistara relief, Borobudur temple; A. Documentation of the plant shape detail, B. Documentation of Lalitavistara relief panel, C. Location of Lalitavistara relief panel in Borobudur temple (blue arrow) 


\section{Identifying the plant figures in Lalitavistara section based on its morphological characters}

The identification was done by comparing the morphological shapes (habitus, root, stem, leaves, flower, and fruit) of plant figures on the reliefs with the most possible plant species (morphological approach). If needed, plant figures on the relief would be sketched to ease the species identification process. Results of identification then adjusted with related references to plant species at the level of species, genus or family.

\section{Comparative study with literature}

The list of flora species in Lalitavistara relief panel was compared with the Lalitavistara Sutra in English translation by the Dharmachakra Translator Committee (2013) and the book of Lalitavistara, The Life of Gautama Budha on The Reliefs of Borobudur Temple (Anandadjoti 2017). This comparison aims to determine the importance of plants that were carved in reliefs, whether plants on the reliefs were subjects in their own right or important objects in the stories; whether they were components of building an atmosphere or just employed as symbols.

\section{Data analysis}

Identified plant figures have been analyzed and grouped based on family and genera. A comparison analysis was made between plant species that appeared in Lalitavistara relief with plant species mentioned in Lalitavistara sutra.

\section{RESULTS AND DISCUSSION}

\section{The important value of plant figures in the story of Lalitavistara relief at Borobudur}

The results of this research showed that all the plant figures carved in the Lalitavistara section can be divided into four categories based on their importance or value. The four categories are:

\section{Plant as the important object in the story of Lalitavistara sutra}

These plants are obviously mentioned or involved in the story of the Lalitavistara as they have a vital role in the story, so they cannot be changed or substituted with another species. The alteration of these species will change the important meaning of the story. Therefore, the illustrations of these species in relief are very strictly guided and should follow the standard from the sutra. Examples for this category are Bodhi tree (Ficus religiosa), Ashoka tree (Saraca asoca), and Lotus (Nelumbo nucifera).

Bodhi tree is a special sacred tree in Buddhism; the Bodhi tree is the holy fig tree. The Bodhi tree is often called the tree of life or the tree of wisdom. In the Lalitavistara relief story, Siddhartha Gautama attained enlightenment (bodhi) while meditating under this tree and came to be known as Buddha later (Dharmachakra 2013; Rutuja et al. 2015; Ram 2016; Anandadjoti 2017; Fauziah et al. 2018). The Bodhi tree is a plant native to India and it is thought that the plant was introduced to the ancient Javanese community along with Buddhism in Java. The ancient Javanese community then recognized the Bodhi tree as a sacred tree (Walujo 2011). It is even said that the outline shape of the stupa in Borobudur has been inspired to the shape of Bodhi tree's leaf.

The name of the Ashoka tree means "without grief" or "one who gives no grief" (Bhalerao et al. 2014; Borokar and Pansare 2017). In the Lalitavistara story, Mayadevi Queen takes a rest in the Ashoka tree forest where she sends a message to Suddhodana King to meet with her (Dharmachakra 2013). It is also thought that Buddha was born under an Ashoka tree and therefore it is often planted in Buddhist monasteries (Roth 2016).

The sacred Lotus may be the most frequent species mentioned in the Lalitavistara sutra. The Lotus flower symbolizes purity, rebirth, and resurrection (Hong 2017). In Buddhist iconography, Buddha is often depicted over an immaculate Lotus and this plant represents bodily and mental purity floating above the muddy waters of attachment to earthly desires (Tresidder 2004). In the Lalitavistara reliefs, the Buddha is very often depicted sitting on a Lotus flower, which symbolizes a person who overcomes the pain that exists in the material world and becomes enlightened, just like the Lotus flower that starts to grow from the dirty and muddy water, but can rise from the water and produce a perfect blossom (Mandal and Bar 2013; Dhammika 2015).

\section{Plant figure as a component in building impression, situation or background (wild forest, beautiful garden, village garden, riverbank and etc.)}

The depictions of plants in this category are more flexible since there is no strict guideline from the sutra. Therefore, the Javanese stone carver usually takes advantage of this category to express themselves. We can intuit the carver's motivation or perspective (as a representative of local community's view in the past) by understanding the plant figures in this category. The examples of this category can be various and are usually inspired by surrounding local plants. The mango plant is a good example in this category. That plant appears very often in the Lalitavistara reliefs to complete various elements in the scenery, from the palace garden, village settlement, to the wild forest.

Moreover, Indonesia (especially Sumatra, Java, and Kalimantan) is one of the richest mango (Mangifera spp.) diversity centers in the world (Shah et al. 2010). It is thought that in the past many mango plants must have been cultivated and grown around the settlements of the ancient Javanese community. According to the Buddhist references such as Tripitaka, Attakatha, and Jataka, the Buddha often stayed overnight near a group of mango trees called Amravana (Bidari 1995). It is also has been assumed that the ancient Javanese community was able to identify various kinds of mango fruits as is mentioned in the text of Kakawin Ramayana (970 AD).

\section{Plant as a symbol}

Plant as a symbol is usually unreal, imaginative, and not based on existing living species. They often been carved with strong stylization and have been used as a symbol of 
certain value, such as prosperity, holiness, fertility, or heavenly realm. The figure of kalpataru tree and sulursuluran plant are two good examples. Kalpataru tree is usually figured as the combination of several plants with vigorous beautiful flowers (Istanto and Syafii 2017). Kalpataru is derived from the word "kalp" means desire or wish, and "taru" which means a tree, therefore kalpataru is kind of tree that can fulfill all the human wishes or needs (Soekmono 1973; Sunaryo 2009). Kalpataru is also symbol of heaven realm, wealth and prosperity (Halim and Herwindo 2017). Meanwhile, the plant named sulursuluran was usually depicted as a creeping plant with many elongated and rolled shoots or tendrils. Sulur-suluran plant is commonly used as a symbol of fertility, sustainable growth, and prosperity (Susannawaty 2008; Halim and Herwindo 2017).

\section{Plant as a part of personal identity or iconography}

Usually, this is a part of a plant (e.g. flower) that is to a certain human figure. The example for this category is a nagakesara (in Sanskrit) or nagasari (in Javanese) plant. In Buddhist iconography, a full bloom nagakesara (Mesua ferrea) flower with or without its branch is a part of Boddhisattva Maitreya's iconography (Banerjee 1975). Therefore, it can be used as a strong clue to identify Maitreya in the relief. However, nagakesara in the form of a whole tree is not related to Maitreya's iconography.

The research in this paper focuses on the examination of the plant figures in categories 1 and 2. This paper also has identified and calculated the plant diversity carved in the Lalitavistara reliefs, without any attention to the individual frequency for each species.

\section{The diversity of plant species carved in Lalitavistara relief at Borobudur temple}

The identification results showed that there were at least 63 plants that can be identified with confidence at the species level (Table 1 and Figures 3-4). However, there were 21 plants that are still unknown since they were difficult to be identified to species level. The difficulties in identification process were mainly due to the poor condition of the reliefs. Heavily eroded plant reliefs were hard to identify since the morphological shape becomes obscured. Another problem was the lack of morphological characters on the plant relief to ease the identification process (example: a plant relief with common shape leaves but without another additional shapes or clue such as fruit and flower). Details of selected plant species carved in Lalitavistara relief are shown in Figure 5.

These 63 identified species consist of 34 different families and 53 different genera. Based on the number of species appearing in the relief of Lalitavistara, several dominant plant families were Fabaceae (8 sp.), Moraceae (6 sp.), Myrtaceae (4 sp.), Apocynaceae (4 sp.), Meliaceae (4 sp.), Arecaceae (3 sp.), Sterculiaceae (3 sp.), Anacardiaceae (2 sp.), Calophyllaceae (2 sp.), Clusiaceae (2 sp.) and Rutaceae (2 sp.) (Figure 3). Fabaceae was the family with the most species in the reliefs of the Lalitavistara, while Syzygium (4 sp.), Ficus (4 sp.), Aglaia (2 $\mathrm{sp}$.$) , Artocarpus (2 sp.), Garcinia (2 sp.) and$ Pterospermum (2 sp.) were several genera with most varied species in the Lalitavistara reliefs.

\section{The plant diversity comparison between Lalitavistara relief and Lalitavistara sutra}

Compared to the plant species written in Lalitavistara sutra, the plants carved in the Lalitavistara reliefs are more varied in the total family, genera, and also species. The total species in Lalitavistara relief consists of 34 families, 53 genera, and 63 species with 21 unidentified figures, while in the Lalitavistara sutra there are 32 families, 44 genera and 54 species with 26 names (Figures 3-4). Based on this diversity, there were 19 similar genera between Lalitavistara relief and Lalitavistara sutra i.e. Areca, Bauhinia, Borassus, Erythrina, Ficus, Magnolia, Mangifera, Mesua, Musa, Nelumbo, Nymphaea, Pterocarpus, Pterospermum, Saccharum, Santalum, Saraca, Shorea, Syzygium and Terminalia (Table 2). The comparison result also showed that there were 19 similar genera between Lalitavistara relief and Lalitavistara sutra. 23 unidentified names in Lalitavistara sutra were presented in Table 3.

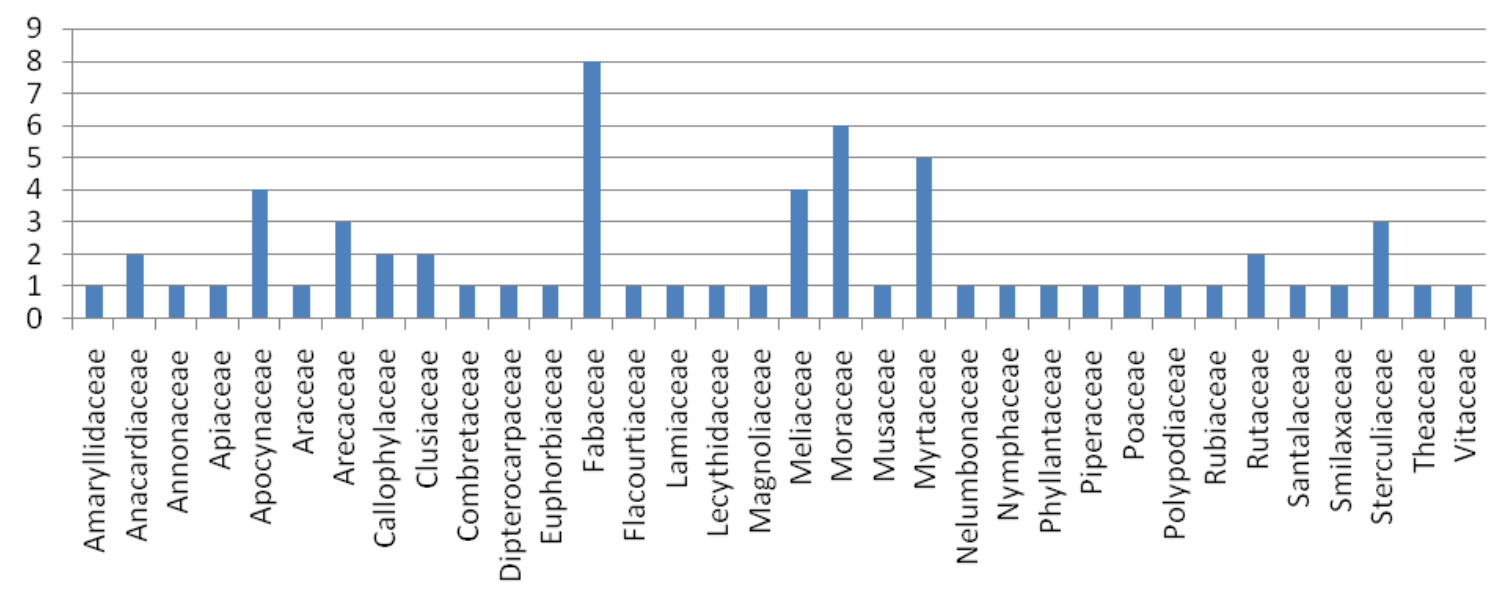

Figure 3. Families of plant species in Lalitavistara relief, Borobudur temple 
Table 1. The identification results of plant species crafted in Lalitavistara relief, Borobudur Temple, Indonesia

\begin{tabular}{|c|}
\hline Plant species \\
\hline Aegle marmelos (L.) Correa \\
\hline Aglaia argentea Blume \\
\hline Aglaia odorata Lour. \\
\hline Aleurites moluccanus (L.) Willd. \\
\hline Alocasia macrorrhizos (L.) G.Don \\
\hline Alstonia scholaris (L.) R.Br. \\
\hline Antidesma bunius (L.) Spreng \\
\hline Areca catechu $\mathrm{L}$. \\
\hline Artocarpus altilis (Parkinson) Fosberg \\
\hline Artocarpus heterophyllus Lam. \\
\hline Barringtonia asiatica (L.) Kurz \\
\hline Bauhinia purpurea $\mathrm{L}$. \\
\hline Borassus flabellifer $\mathrm{L}$. \\
\hline Calophyllum inophyllum $\mathrm{L}$. \\
\hline Calotropis gigantea $($ L.) W.T. Aiton \\
\hline Cayratia trifolia (L.) Domin \\
\hline Centella asiatica (L.) Urb. \\
\hline Cerbera odollam Gaertn. \\
\hline Cocos nucifera $\mathrm{L}$. \\
\hline Crinum asiaticum $\mathrm{L}$. \\
\hline Dysoxylum parasiticum (Osbeck) Kosterm. \\
\hline Erythrina variegata L. \\
\hline Flacourtia rukam Zoll. \& Moritzi \\
\hline Ficus benjamina $\mathrm{L}$. \\
\hline Ficus elastica Roxb. Ex Hornem \\
\hline Ficus microcarpa L.f. \\
\hline Ficus religiosa $\mathrm{L}$. \\
\hline Garcinia dulcis (Roxb.) Kurz \\
\hline Garcinia mangostana $\mathrm{L}$. \\
\hline Gluta velutina Blume \\
\hline Kleinhovia hospita $\mathrm{L}$. \\
\hline Lagerstroemia speciosa (L.) Pers. \\
\hline Limonia acidissima $\mathrm{L}$. \\
\hline Leptochilus pteropus subsp. Pteropus \\
\hline Mangifera sp. \\
\hline Maniltoa browneoides Harms \\
\hline Mesua ferrea $\mathrm{L}$. \\
\hline Magnolia champaca (L.) Baill. Ex Pierre \\
\hline Mimusops elengi L. \\
\hline Morinda citrifolia $\mathrm{L}$. \\
\hline Musa sp. \\
\hline Nelumbo nucifera Gaertn. \\
\hline Nymphaea rubra Roxb. ex Andrews \\
\hline Piper betle L. \\
\hline Pterocarpus indicus Willd. \\
\hline Pterospermum acerifolium (L.) Willd. \\
\hline Pterospermum diversifolium Blume \\
\hline Saccharum officinarum $\mathrm{L}$. \\
\hline Sandoricum koetjape (Burm.f.) Merr. \\
\hline Santalum album $\mathrm{L}$. \\
\hline Saraca asoca (Roxb.) J.J. de Wilde \\
\hline Schima wallichii (DC) Korth. \\
\hline Shorea robusta C.F. Gaertn. \\
\hline Smilax leucophylla Blume \\
\hline Stelechocarpus burahol (Blume) Hook.f. \& Thomson \\
\hline Syzygium jambos (L.) Alston \\
\hline Syzygium aqueum (Burm.f.) Alston \\
\hline Syzygium malaccense (L.) Merr. \& L.M. Perry \\
\hline Syzygium samarangense (Blume) Merr. \& L.M. Perry \\
\hline Tamarindus indica $\mathrm{L}$. \\
\hline Tectona grandis L.f. \\
\hline Terminalia catappa $\mathrm{L}$. \\
\hline Voacanga foetida (Blume) Rolfe \\
\hline
\end{tabular}

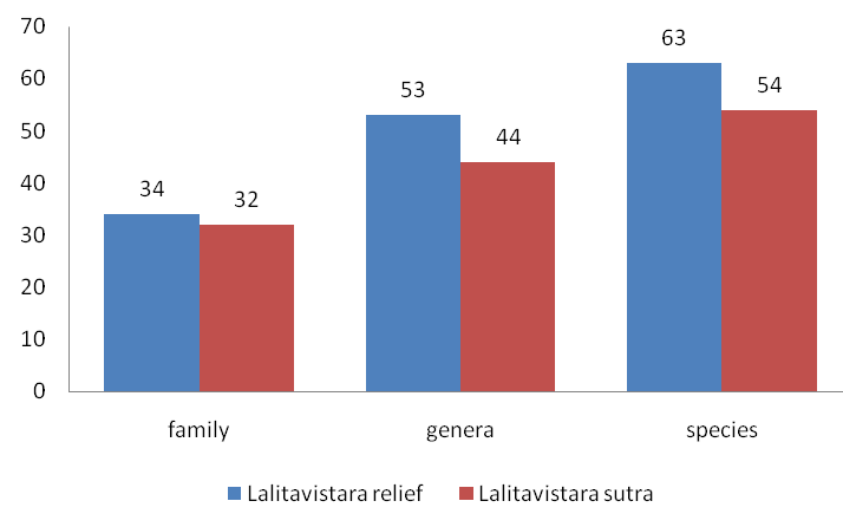

Figure 4. Comparison of family, genera, and species total from plant species in Lalitavistara relief with Lalitavistara sutra

\section{Discussion \\ Plant relief as an information source and reflection of plant diversity in ancient history}

Based on the number of species that appear in the reliefs, several dominant plant families carved in the Lalitavistara at Borobudur were Fabaceae, Moraceae, Myrtaceae, Apocynaceae, Meliaceae, Arecaceae, Sterculiaceae, Anacardiaceae, Calophyllaceae, Clusiaceae, and Rutaceae. Fabaceae was the family with the most species appeared in relief of Lalitavistara. There were about 8 species in Fabaceae that were carved randomly in relief, such as Bauhinia purpurea, Erythrina variegata, Lagerstroemia speciosa, Maniltoa brownioides, Mimusops elengi, Pterocarpus indicus, Saraca asoca, and Tamarindus indica. While in Moraceae, there were 6 species that have been carved in the Lalitavistara reliefs, such as Artocarpus altilis, A. heterophyllus, Ficus benjamina, F. elastica, F. microcarpa, and F. religiosa. These dominant families must have been familiar plants for the ancient Javanese community. The importance and value of those plants for the ancient community may be very diverse from timber, traditional culinary, to the sacred and iconic religious tree.

Plant symbols in reliefs indicate a deep connection between ancient humans and environment. In the past, representations of plants not only were made for decorative or aesthetic reasons but also had a precise symbolic aim (Day 2013; Yilmaz et al. 2013; Caneva et al. 2014; Savo et al. 2016). Tanjung (M. elengi) and Asam Jawa (T. indica) are the examples of Fabaceae member that have long historical usage in the ancient Javanese community daily life. Tanjung tree is a native species to India (Kiyasudeen and Ismail 2013) and Indonesia that has been considered as one of seven sacred trees associated with Buddha (Amirthalingam 1998). At one time, the Tanjung tree was planted near the holy temples in Java as is written in the Siwagrha inscription (856 AD). This tree may have provided aromatic fragrance and helped establish a peaceful atmosphere for deep meditation (Gupta 2013). Meanwhile, Asam Jawa is thought to be a tropical Africa native species that have been purposely introduced by trade to India and Southeast Asia since thousand years ago. As is written in several inscriptions (Paradah - 943 AD, Lintakan 
Table 2. Genera comparation of plant species between Lalitavistara relief and Lalitavistara sutra

\begin{tabular}{|c|c|c|c|c|c|}
\hline \multicolumn{3}{|c|}{ Genera of plant species in Lalitavistara relief } & \multicolumn{3}{|c|}{ Genera of plant species in Lalitavistara sutra } \\
\hline Aegle & Dysoxylum & Nymphaea & Orchids & Gossypium & Rosa \\
\hline Aglaia & Erythrina & Piper & Aquilaria & Hibiscus & Saccharum \\
\hline Aleurites & Flacourtia & Pterocarpus & Areca & Hordeum & Santalum \\
\hline Alocasia & Ficus & Pterospermum & Bambusa & Imperata & Saraca \\
\hline Alstonia & Garcinia & Saccharum & Bauhinia & Jasminum & Sesamum \\
\hline Antidesma & Gluta & Sandoricum & Borassus & Juniperus & Shorea \\
\hline Areca & Kleinhovia & Santalum & Brassica & Magnolia & Syzygium \\
\hline Artocarpus & Lagerstroemia & Saraca & Campsis & Mangifera & Terminalia \\
\hline Barringtonia & Limonia & Schima & Coccinia & Manilkara & Valeriana \\
\hline Bauhinia & Mangifera & Shorea & Couroupita & Mesua & \\
\hline Borassus & Maniltoa & Smilax & Crocus & Millettia & \\
\hline Calophyllum & Mesua & Stelechocarpus & Cynodon & Musa & \\
\hline Calotropis & Magnolia & Syzygium & Deschampsia & Myristica & \\
\hline Cayratia & Microsorum & Tamarindus & Desmotachya & Nelumbo & \\
\hline Centella & Mimusops & Tectona & Dianthus & Nymphaea & \\
\hline Cerbera & Morinda & Terminalia & Diospyros & Pterocarpus & \\
\hline Cocos & Musa & Voacanga & Erythrina & Pterospermum & \\
\hline Crinum & Nelumbo & & Ficus & Oryza & \\
\hline
\end{tabular}

*) Bold type indicates same genera between relief and sutra of Lalitavistara

Table 3. Plant species of Lalitavistara sutra

\section{Plant species in Lalitavistara sutra}

\section{Identified plant species}

Aquillaria malaccensis Lam. (Aloe wood/ Black aloe wood)

Areca sp. (Jewel palm trees/ palm)

Bambusa sp. (Bamboo)

Bauhinia variegata L. (Kovidara tree)

Borassus flabellifer $\mathrm{L}$. (Tala trees)

Brassica juncea (L.) Czern. (Mustard seed)

Campsis radicans (L.) Bureau (Trumpet vines)

Coccinia grandis (L.) Voight. (Bimba fruit)

Couroupita guianensis Aubl. (Naga/ Sala flowers)

Crocus sativus L. (Saffron trees)

Cynodon dactylon (L.) Pers. (Durva grass)

Deschampsia cespitosa (L.) P. Beauv. (Golden hued flowers)

Desmostachya bipinnata (L.) Stapf (Kusa grass/ Darbha grass)

Dianthus caryophyllus L. (Divine flowers)

Diospyros celebica Bakh. (Enonies/ Mountain ebonies)

Diospyros kaki L.f. (Persimmon)

Erythrina variegata L. (Mandarava/Maha Mandarava flower/

\section{Coral trees)}

Ficus benghalensis L. (Nyagrodha tree/ Banyan tree)

Ficus carica L. (Fig tree)

Ficus racemosa L. (Udumbara flowers)

Ficus religiosa L. (Bodhi tree/ King of trees)

Gossypium hirsutum L. (Cotton)

Hibiscus rosa-sinensis L. (Hibiscus)

Hordeum vulgare L. (Barley grains)

Imperata cylindrica (L.) P. Beauv. (Valvaja grass)

Jasminum multiflorum (Burm.f.) (Malikas)

Jasminum sp. (Coral jasmine/ Jasmine)

Juniperus communis L. (Juniper berry)

Magnolia champaca (L.) Baill. Ex Pierre

Magnolia sp. (Magnolia)

Manilkara hexandra (Roxb.) Dubard (Milk tree)

Mesua ferrea L. (Kesaras)

Millettia piscidia (Roxb.) Wight \& Arn. (Sumanas)

Musa sp. (Plantain tree)

Myristica fragrans Houtt. (Nutmeg blossom)

Nelumbo nucifera Gaertn. (Lotus/ pink lotus/ red lotus)

Nymphaea nouchali var. caerulea (Savigny) Verdc. (Blue lotus)

Nymphaea lotus L. (White lotuses)

Nymphaea nouchali Burm.f. (Water lilies)
Nymphaea sp. (Lilies)

Orchid

Oryza sativa L. (Rice grain)

Pterocarpus indicus Willd. (Narras)

Pterospermum acerifolium (L.) Willd. (Karnikaras/ Bayur tree)

Rosa chinensis Jacq. (Rose)

Saccharum officinarum L. (Sugarcanes)

Saccharum bengalense Retz. (Munja grass)

Santalum album L. (Sandalwood)

Saraca asoca (Roxb.) J.J. de Wilde (Ashoka tree)

Sesamum indicum L. (Sesame seed)

Shorea robusta C.F. Gaertn. (Salas)

Syzygium jambos (L.) Alston (Rose apple tree)

Terminalia chebula Retz. (Myrobalan fruit)

Valeriana jatamansi Jones ex Roxb. (Tagala)

Non identified plant species

Abhimuktaka flower

Bali

Barasikas

Beautiful Tree

Black Aloe Wood

Celestial flower

Danukari flower

Dhanuskari flowers

Divine flowers

Excellent trees

Exquisite flowers

Flower garlands

Fragrant garland

Golden lotus

Herbs

Holding flowers

Jyotis

Kotaranis

Lord of trees

Maha-Muchalindas

Muchalindas

Rise

Silk canopies

Single berry

Taranis

Tree bark

*) Bold type indicates same species between relief and sutra of

Lalitavistara; sentences in parentheses is Sanskrit or English names in Lalitavistara sutra 

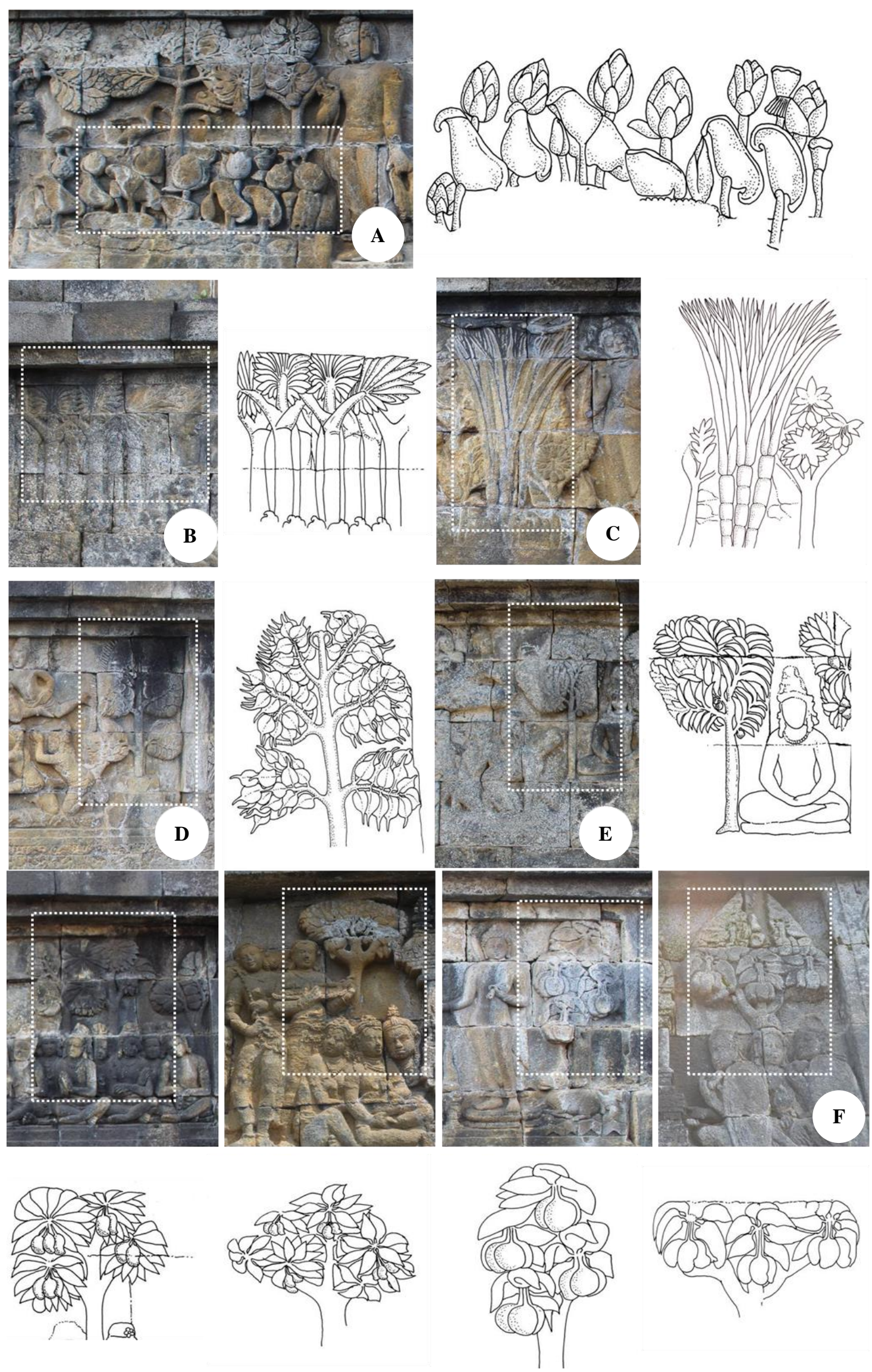

Figure 5. Selected plant species in relief of Lalitavistara; A. Nelumbo nucifera Gaertn (Nelumbonaceae), B. Borassus flabellifer L. (Arecaceae), C. Saccharum officinarum L. (Poaceae), D. Ficus religiosa L. (Moraceae), E. Syzygium jambos (L.) Alston (Myrtaceae), and F. the diversity of Mangifera spp. (Anacardiaceae) 
- 919 AD, Sangguran - 928 AD, and Rukam - 907 AD), the ancient Javanese community has known Asam Jawa as a part of traditional culinary art, especially for the traditional drink named Cinca or Kinca (Swandayani 1989; De Caluwe et al. 2010; Taqyuddin and Susanti 2016). The fruit of Asam Java also has been traded as one of important commodities of Sunda Kingdom (10 ${ }^{\text {th }}$ Century) (Saptono 2017).

At the genus level, Syzygium was the genus with the most diverse species appearing in the Lalitavistara section (4 species), including $S$. jambos, $S$. aqueum, S. malaccense and S. samarangense. Genus Mangifera also has many diverse species appearing in the Lalitavistara reliefs (even perhaps exceeding the diversity of Syzygium species). However, since it quite difficult and takes more time to identify all the Mangifera's reliefs specifically, therefore in this paper the authors have included all of those variations under one taxon named Mangifera spp. Another diverse genus was Ficus spp. with 4 species, including $F$. benjamina, F. elastica, F. microcarpa and $F$. religiosa.

Although Lalitavistara sutra has been used as important guide in designing the Lalitavistara reliefs, not all plant species mentioned in Lalitavistara sutra carved in the Lalitavisata's section at Borobudur. There are only 14 spesies which were mentioned in the Lalitavistara sutra as well as carved in the Lalitavistara relief in Borobudur. These species include Areca catechu, Borassus flabellifer, Erythrina variegata, F. religiosa, Magnolia champaca, Mangifera spp., M. ferrea, Nelumbo nucifera, Pterocarpus indicus, Pterospermum acerifolium, Saccharum officinarum, Santalum album, Saraca asoca and Syzygium jambos (Table 3). Among those 14 species, 2 species are known to be Indonesian native species ( $S$. album (Jones et al. 2009; Arifriana et al. 2017) and S. officinarum (Henry and Kole 2010; OECD 2013), 3 species are known to be native Indian ( $F$. religiosa, $N$. nucifera and $S$. asoca (Preeti et al. 2012)), while the other 9 species (A. catechu, B. flabellifer, E. variegata, M. champaca, Mangifera spp., M. ferrea, $P$. indicus, $P$. acerifolium and $S$. jambos) can be found or have been naturalized in both Indian and Indonesian regions. These overlapping species perhaps have a role as vital or important irreplaceable object in the Lalitavistara story, and/or they are well-known plants for both communities, Indian and Javanese (Indonesia), or at least they were easily domesticated in both regions. The fact that there are several Indonesian native plants written in the Lalitavistara sutra ( $3^{\text {rd }}$ Century) and also Indian native plants carved accurately in the Borobudur wall $\left(8-9^{\text {th }}\right.$ Century), has strengthened the allegation that plant species exchange existed at that time or even long time before, especially through cross-regional trade or religion-related activity (Sastri 1940; Read 2008; Jones et al. 2009).

According to the natural distribution of the plant species carved in the Lalitavistara relief, it can be known that the environmental setting depicted is a combination between tropical India flora and Indonesian flora (especially Sumatra and Java Islands). Some examples of identified species in reliefs that are native from India and are not naturally distributed in Indonesia, i.e. N. nucifera, F. religiosa, Aegle marmelos and S. asoca. On the other side, some example of identified species that are native to Indonesia (Sumatra and Java) and are not naturally distributed in India, i.e. S. aqueum, S. samarangense, Areca spp. and Dysoxylum parasiticum. In addition, plant species appeared in the Lalitavistara relief at Borobudur mostly is typical of tropical lowland species, or at least they are adaptive to lowland habitat as one of their natural distribution ranges (eg. Cocos nucifera, Musa spp., Mangifera spp., S. album and Calophyllum inophyllum). Therefore, by combining previous explanations it can be known that the plant reliefs in the Lalitavistara section at Borobudur show a typical tropical lowland environment in Indonesia (especially Sumatra and Java) with a few combinations of tropical lowland environment in India.

\section{The diversity of plant relief in Lalitavistara-Borobudur in} relation to the perspective of ancient Javanese community

As one of the important centers for Buddhist scholarship and worship, especially in Southeast Asia $\left(7^{\text {th }}\right.$ $\left.15^{\text {th }}\right)$, Borobudur has been visited by many pilgrims and scholars from various places to learn about Mahayana Buddhism (Wiener 2018). Reliefs at Borobudur functions as depiction of the religious text in visual scenery. This approach makes easier delivering the essential message to a wider audience, as well as to those who are illiterate (Gifford 2011). Therefore, scenery carved in a relief panel should be able to represent some parts of the story of the Lalitavistara sutra. Sometimes, there are parts of the story that mention or describe a certain situation or background, such as wild forest, riverbanks, villages, royal gardens, etc. Since the Lalitavistara sutra doesn't always describe a natural environment (as a story background) in detail, there is an opportunity for the carvers to develop their own perception (Istari 2015).

The carvers, who also can be considered as a representative of ancient Javanese community at that time, very often illustrate the natural environment with scenery of various plants (various in size, shape, stage) from their own experience. Different types of environment showed different plant diversity (Hattermann et al. 2018). For example, scenery of wild forests was depicted with a more various wild plant species than village gardens or royal gardens. The appropriate natural environment is very often being interpreted or perceived by the ancient Javanese community with richness in plant species.

The number of plant species in the Lalitavistara reliefs which is more diverse than in Lalitavistara sutra can be an indication that the ancient Javanese community at that time had a high awareness in plant diversity. They tried to depict the plant diversity as much as possible (especially those that were familiar in their daily life). Technically, carving plant figures using monotonous shapes or with few variations requires much less effort, is more efficient and will make the carver's work easier. But in fact, they even put more various shapes of plants in their carving. Every part of each identified plant species in the Lalitavistara reliefs has been carved appropriately and quite consistent with the real living species. This means that the carvers had a sufficient basic knowledge in plant morphology or at least they were familiar with the distinctive morphology in 
many plant species. Therefore, it could be proposed that plant diversity was a very important value in the ancient Javanese community, so important that it needed to be expressed, even in a "holy" and "precious" medium such as the Lalitavistara reliefs in Borobudur. Because cultural and important value of plant diversity give benefit to people community (Helida et al. 2015). Based on the above explanations, it is clear that the ancient Javanese community had a high appreciation to the plant diversity as a reflection of naturalness and an "ideal" environment.

\section{ACKNOWLEDGEMENTS}

This study was fully funded by DIPA of Research Center for Biology, Indonesian Institute of Sciences (LIPI) through the IBSAP (International Biodiversity, Strategic and Action Plan) program year 2019. The author would like to acknowledge the team from Borobudur Conservation Office. For author contributor, DM, F, and DAL are main contributor.

\section{REFERENCES}

Amirthalingam M. 1998. Sacred Groves of Tamilnadu. C.P.R. Environment Education Centre, Chennai.

Anandadjoti. 2017. Lalitavistara The Live of Gautama Budha on The Reliefs of Borobudur Temple. Ehipassiko Foundation, Jakarta. [Indonesian]

Arifriana R, Indrioko S, Syahbudin A. 2017. Variation of sandalwood (Santalum album Linn.) based on morphology of leaves and flowers at Petir village, Rongkop, Gunungkidul. J For Sci 2: 97-108.

Banerjee P. 1975. The story of Rupananda from Bamiyan, Afganistan. Bull Tibetol 12 (1): 20-24.

Bhalerao SA, Verma DR, Didwana VS, Teli NC. 2014. Saraca asoca (Roxb.), De. Wild: An overview. Ann Plant Sci 3 (07): 770-775.

Bidari B. 1995. Forest and Trees Associated with Buddha's Life. Proceedings of The Planning Workshop on The Restoration of Wetlands in Lumbini. IUCN Nepal and Lumbini Development Trust, Lumbini. 17-18 December 1995.

Borokar AA, Pansare TA. 2017. Plant profile, phytochemistry and pharmacology of Ashoka (Saraca asoca (Roxb.), De. Wilde) - A comprehensive review. Int. J. Ayurvedic Herb. Med. 7 (2): 2524 2541.

Brink VD. 1931. Welke planten vindt men op de Boroboedoer afgebeeld. De Tropische Natuur 20 (8): 181-186.

Cammerloher H. 1931. Wat de Borobudur den natuuroderzoeker leert. De Tropische Natuur 20 (8): 141-152.

Caneva G, Savo V, Kumbaric A. 2014. Big messages in small details: nature in Roman archeology. Econ Bot 68: 109-115.

Day J. 2013. Botany meets archaeology: people and plants in the past. J Exp Bot 64 (18): 5805-5816.

De Caluwe E, Halamova K, Van Damme P. 2010. Tamarindus indica L. a review of traditional uses, phytochemistry and pharmacology. Afr Focus 23 (1): 53-83.

Dhammika S. 2015. Nature and The Environment in Early Buddhism. Buddha Dharma Mandala Society, Singapore.

Dharmachakra Translation Committee. 2013. The Noble Great Vehicle Sūtra "The Play in Full" (Āryalalitavistaranāmamahāyānasūtra). Toh 95, Dege Kangyur 46: 1b-216b.

Fauziah, Yulistyarini T, Lestari DA, Ariyanti EE, Metusala D, Damaiyani J, Patmiati, Matrani. 2018. Guidebook of Educational Tourism of Flora Reliefs in Borobudur Temple. Purwodadi Botanic Garden in collaboration with Biology Research Center and Borobudur Conservation Center, Pasuruan. [Indonesian]

Gifford R. 2011. The dragons of inaction: Psychological barriers that limit climate change mitigation and adaptation. Am Psychol 66 (4): 290302.
Gunarto H. 2011. Digital Preservation of Borobudur World Heritage and Cultural Treasures. Ritsumeikan Center for Asia Pasific Studies (RCAPS) Research Report, Japan.

Gupta PC. 2013. Mimusops elengi Linn. (Bakul) - A potential medicinal plant: A review. Int J Pharm Phytopharmacol Res 2 (5): 332-339.

Halim A, Herwindo RP. 2017. The meaning of ornaments the Hindu and Buddhist temples on the island of Java (ancient-middle-late classical eras). Jurnal Riset Arsitektur 1 (2): 170-191. [Indonesian]

Hattermann D, Bernhardt-Romermann M, Otte A, Eckstein RL. 2018. New insights into island vegetation composition and species diversity - consistent and conditional responses across contrasting insular habitats at the plot-scale. PloS ONE 13 (7): e0200191. DOI: 10.1371/journal.pone.0200191.

Helida A, Zuhud EAM, Hardjanto, Purwanto, Hikmat A. 2015. Index of cultural significance as a potential tool for conservation of plants diversity by communities in the Kerinci Seblat National Park. J Trop For Manag 21 (3): 192-201.

Henry RJ, Kole C. 2010. Genetics, Genomic, and Breeding of Sugarcane. Taylor \& Francis Group, LLC. Science Publishers, USA.

Hermawan B, Salim U, Rohman F, Rahayu M. 2016. Borobudur temple as Buddhist Pilgrimage destination in Indonesia: an analysis of factors that affect visit intention. J Int. Buddh. Stud. 7 (2): 98-110.

Hidayanto AF. 2014. Study of panil 13 meaning, at Lalitavistara relief of Borobudur temple. J Creative: Ind Architect Prod Design 1 (2): 55-66. [Indonesian]

Hong EJ. 2017. Lotus: symbol of rebirth and resurrection. Eurasian J Anal Chem 13 (3): 1-8.

Istanto R, Syafii. 2017. Ornamental variety of kalpataru tree in Prambanan. Imajinasi 11 (1): 19-28. [Indonesian]

Istari TRM. 2015. The Ornamental Variety of Temples in Java (Motifs and Their Meanings). Kepel Press, Yogyakarta. [Indonesian]

Jones CG, Plummer JA, Barbour L, Byrne M. 2009. Genetic diversity of an Australian Santalum album collection - implications for tree improvement potential. Silvae Genet 58 (5): 279.

Kempers AJ, Bernet, Soekmono. 1974. Mendut Temple, Pawon and Borobudur. Ganaco NV., Bandung. [Indonesian]

Kiyasudeen K, Ismail SA. 2013. Pest repellent potential of Mimusops elengi against some cmmon pests in Jasminum sambac cultivation. Int. J. Life Sci. Res 1 (1): 5-10.

Leouw AWY. 2012. The influence of Buddhism in Central Java: interpretations of Mudras of Borobudur's temple Buddhist monuments. J Tourism, Hospitality and Culinary Arts 4 (2): 66-81.

Mandal RN, Bar R. 2013. The sacred lotus, an incredible wealth of wetlands. Resonance 18 (8): 732-737.

Miksic J, Tranchini M. 1990. Borobudur: Golden Tales of Buddhas. Shambhala Pub., Boston.

Organisation for Economic Co-operation and Development (OECD). 2013. Consensus Document on the Biology of Sugarcane (Saccharum spp.). Environment Directorate Organisation for Economic Cooperation and Development, Paris.

Preeti B, Bharti A, Sharma AN, Vishwabhan S. 2012. A review on Saraca indica plant. Intl Res J Pharm 3 (4): 80-84.

Ram HYM. 2016. Iconic flora of heritage significance in India. Indian J History Sci 51 (2): 312-342.

Read RD. 2008. Exploring The Maritime Influence of Archipelago Civizations in Africa. Mizan, Bandung. [Indonesian]

Rohyani S. 2004. Scenario of Karmawibhangga Relief in Borobudur Temple. University of Indonesia, Jakarta. [Indonesian]

Roth JJ. 2016. A Brief Guide to The Sacred Trees of India. https://www.talesbytrees.com/a-brief-guide-to-the-sacred-trees-ofindia/. [29 January 2020].

Rutuja RS, Shivsharan U, Shruti MA. 2015. Ficus religiosa (Peepal): A phytochemical and pharmacological review. Intl J Pharm Chem Sci 4 (3): 360-370.

Saptono N. 2017. Maritime Activities of The Sunda Kingdom Period. https: //kebudayaan.kemdikbud.go.id/ditpcbm/aktifitas-kemaritimanmasa-kerajaan-sunda/. Accessed on October 25, 2019. [Indonesian]

Sastri NK. 1940. Sri Vijaya. In: Bulletin de l'Ecole française d'ExtrêmeOrient. Tome $40 \mathrm{~N}^{\circ} 2$. pp. 239-313.

Savo V, Kumbaric A, Caneva G. 2016. Grapevine (Vitis vinifera L.) symbolism in the ancient euro-mediterranean cultures. Econ Bot 70 (2): 190-197.

Setyawan H, Kasatriyanto B. 2019. Study on the vegetation planning for Borobudur area. Borobudur 13 (2): 3-31. 
Setyawan H. 2017. Plants Species and Contexts of Their Descriptions on Relief of Borobudur and Mendut Temples. Report on The Study of Vegetation Management in Borobudur Area, Magelang. [Indonesian]

Shah KA, Patel MB, Patel RJ, Parmar PK. 2010. Mangifera indica (mango). Pharmacognosy Rev 4 (7): 42-48

Soekmono R. 1973. Introduction to The History of Indonesian Culture. Kanisius, Yogyakarta. [Indonesian]

Steinman A. 1934. De op de Boroboedoer Afgebeelde Plantenwereld. In: Setyawan H, Kasatriyanto B. 2019. Study on the vegetation planning for Borobudur area. Borobudur 13 (2): 3-31.

Sunaryo A. 2009. Buddhist temple ornaments: a study of the shapes and patterns of Borobudur, Mendut and Pawon temples. Imajinasi 5 (2): 247-265. [Indonesian]

Sunaryo A. 2010. Various ornaments of flora motifs in Karmawibhangga relief, Borobudur temple. Imajinasi 6 (2): 113-125. [ Indonesian]

Susannawaty A. 2008. Study of the form and symbolic meaning of figures in the Majapahit earthenware (Hayam Wuruk period 1350-1389 AD). J Visual Art Design 2 (2): 123-140. [Indonesian]

Susilo YS, Suroso A. 2014. Integrated management of Borobudur world heritage site: A conflict resolution effort. Asia Pacific Manag. Busin. Appl. 3 (2): 116-134.
Swandayani A. 1989. Food and Beverage of Ancient Javanese 9-10 AD: A Study Based on Inscription and Manuscript Sources. [Thesis]. Department of Archaeological, Faculty of Cultural Studies, University of Indonesia, Jakarta. [Indonesian]

Taqyuddin, Susanti N. 2016. Food Culture and Land Use in Ancient Times. Proceedings of The Asia-Pacific Research in Social Sciences and Humanities-Universitas Indonesia Conference. University of Indonesia, Jakarta, 13 October 2016.

Tresidder J. 2004. The Complete Dictionary of Symbols in Myth, Art and Literature. Duncan Baird Publishers, London.

Walujo EB. 2011. Contribution of Botany in Facilitating Human Relations with Plants and The Environment. Jurnal Biologi Indonesia 7 (2): 375-391. [Indonesian]

Wiener JB. 2018. Borobudur. https: //www.ancient.eu/Borobudur/. [20 February 2018].

Yilmaz H, Akkemik U, Karagoz S. 2013. Identification of plant figures on stone statues and sarcophaguses and their symbols: the hellenistic and Roman periods of the eastern mediterranean basin in the Istanbul archaeology museum. Mediterr Archaeol Archaeom 13 (2): 135-145. 